\title{
The Effect of miR-34a-5p and miR-145-5p Ectopic Expression on Cell Proliferation and Target Gene Expression in the MDA-MB-231 Cell Line
}

\author{
miR-34a-5p ve miR-145-5p'nin MDA-MB-231 Hücre Hattındaki Ektopik Ekspresyonunun \\ Hücre Proliferasyonu ve Hedef Gen Ekpresyonu Üzerindeki Etkisi
}

\author{
(1) ilknur SUER ${ }^{1}$, (1) Murat KAYA2 , (1) Emre ÖZGÜR ${ }^{3}$ \\ 1 istanbul University-istanbul Faculty of Medicine, Department of Medical Genetics, istanbul, Turkey \\ 2 istanbul University-istanbul Faculty of Medicine, Department of Internal Diseases, Division of Medical Genetics, Istanbul, Turkey \\ 3 istanbul University, Oncology Institute, Diagnostic Treatment and Care Services, Department of Basic Oncology, Istanbul, Turkey
}

\begin{abstract}
Aim: It was aimed to investigate the effect of miR-34a-5p and miR-145-5p on breast cancer cell line MDA-MB-231 and to determine the expression of target genes of these microRNAs (miRNAs).

Materials and Methods: Firstly, literature search and in silico analysis were performed to detect possible target genes of miR-34a-5p and miR-145$5 p$, which are known to be tumor suppressors. Mimic miR-34a-5p and miR-145-5p were transfected to the breast cancer cell line MDA-MB-231. Deregulated genes were investigated by the quantitative real-time polymerase chain reaction compared to control cells. Also, the effect of these miRNAs on proliferation was determined using the Water Soluble Tetrazolium Salt-8 method. Finally, the expressions of epithelial mesenchymal transition (EMT) markers, which are known to be important in the metastatic process, are examined.

Results: The proliferation of the miR-34a-5p or miR-145-5p transfected cells decreased compared to the control groups. The expression of E2F transcription factor $1(E 2 F 1)(p=0.009)$, mitogen activated protein kinase $1(M E K 1)(p=0.001)$ and cyclin dependent kinase $4(C D K 4)(p=0.005)$ genes, which were among the genes targeted by miR-34a-5p, were significantly reduced. EMT markers were significantly changed in miR-34a-5p transfected cells ( $E$-Cad increase $p=0.01$; Vimentin decrease $p=0.008$ ). Kruppel-like factor 4 (KLF4) ( $p=0.007)$ targeted miR-145-5p were significantly reduced and EMT markers were significantly changed in miR-145-5p transfected cells ( $E$-Cad increase $p=0.0005$; Vimentin decrease $p=0.006$ ).

Conclusion: miR-34a-5p and miR-145-5p may have an impact on the breast cancer cell line MDA-MB-231 proliferation and EMT mechanism. At the same time, according to our study results, it was revealed that E2F1, MEK1 and CDK4 genes, whose expression level decreased after transfection of mimic miR-34a-5p, could be targeted by miR-34a-5p in breast cancer, and that the expression level of KLF4, which decreased as a result of mimic miR-145-5p transfection, could be the target.
\end{abstract}

Keywords: MDA-MB-231, breast cancer, miRNA, miR-34a-5p, miR-145-5p

ÖZ

Amaç: Bu çalışmada miR-34a-5p ile miR-145-5p'nin meme kanseri hücre hattı MDA-MB-231 üzerindeki fonksiyonel etkilerinin araştııılması ve bu mikroRNA'ların (miRNA) olası hedef genlerinin miRNA mimik transfeksiyonu yapılan hücrelerde ifade seviyelerinin araştırılması hedeflenmiştir.

Gereç ve Yöntem: Tümör baskılayııı özellikte oldukları bilinen miR-34a-5p ve miR-145-5p'nin meme kanserindeki olası hedef genlerinin tespiti için öncelikle literatür taraması ve in silico analiz çalışması yapılmıştır. Tespit edilen genlerin ifadelerindeki değişimler in vitro ortamda meme kanseri hücre hattı MDA-MB-231'de belirlenen miRNA'ların transfekte edilmesiyle kontrol hücrelerle karşılaştırmalı olarak kantitatif gerçek zamanlı polimeraz zincir reaksiyonu ile araştıııması hedeflenmiştir. Ayrıca bu miRNA'ların proliferasyona etkisi Water Soluble Tetrazolium Salt-8 yöntemi kullanılarak belirlenmiştir. Son olarak metastatik süreçte önemli olduğu bilinen epitelyal mezenkimal geçiş (EMT) belirteçlerinin ekspresyonuna bakılarak metastaza olan katkısının araştııııması hedeflenmiştir.

Address for Correspondence: IIlknur SUER PhD, İstanbul University, İstanbul Faculty of Medicine, Department of Internal Diseases, Division of Medical Genetics, istanbul, Turkey Phone: +90 5055401047 E-mail: ilknursuer@gmail.com, ilknursuer@istanbul.edu.tr ORCID ID: orcid.org/0000-0003-1954-4190

Received: 16.07.2020 Accepted: 22.03.2021

๑Copyright 2021 by the Tekirdağ Namık Kemal University Faculty of Medicine / Namık Kemal Medical Journal published by Galenos Publishing House. 
Bulgular: miR-34a-5p transfeksiyonu yapılan gruptaki hücre proliferasyonunun kontrol grubu hücrelere göre azaldığı, EMT ile ilişkili genlerin ifadesinin anlamlı şekilde değiştiği ( $E$-Cad artış $p=0,01$; Vimentin azalma $p=0,008$ ), miR-34a-5p'nin hedeflediği genlerden olan E2F transkripsiyon faktör $1(E 2 F 1)(p=0,009)$, mitojen aktive protein kinaz $1(M E K 1)(p=0,001)$ ve siklin bağımlı kinaz $4(C D K 4)(p=0,005)$ genlerinin ifadesinin belirgin şekilde düştüğü tespit edilmiştir. miR-145-5p transfekte edilen hücrelerde ise benzer şekilde hücre proliferasyonunda azalma ve EMT ile ilişkili genlerde anlamlı değişiklikler gözlenmiş ( $E$-Cad artış $p=0,0005$; Vimentin azalma $p=0,006$ ), miR-145-5p'nin hedeflediği önemli proto onkogenlerden birisi olan Kruppel-benzeri faktör 4 (KLF4) ( $p=0,007)$ geninin ifadesinin önemli derecede azaldığı tespit edilmiştir.

Sonuç: Çalışma sonuçlarımız, miR-34a-5p ve miR-145-5p'nin meme kanseri hücre hattı MDA-MB-231 hücre proliferasyonu ve EMT mekanizması üzerinde etkili olabileceğini göstermiştir. Aynı zamanda çalışma sonuçlarımıza göre mimik miR-34a-5p transfeksiyon yapılması sonrasında ekspresyon seviyesi azalan E2F1, MEK1 ve CDK4 genlerinin meme kanserinde miR-34a-5p tarafından hedeflenebileceği, yine mimik miR-145-5p transfeksiyonu neticesinde ifade seviyesi azalan KLF4 geninin miR-145-5p'nin hedefi olabileceği ortaya çıkmıştır.

Anahtar Kelimeler: MDA-MB-231, meme kanseri, miRNA, miR-34a-5p, miR-145-5p

\section{INTRODUCTION}

Breast cancer is the most common type of cancer in women, and it occupies a large place among cancer-related deaths in women all over the world, especially among women in underdeveloped countries'. MicroRNAs (miRNAs) are singlestranded, non-protein-coding RNAs containing approximately 19-24 nucleotides and repress their target mRNAs. Depending on the functions of target genes, miRNAs are biomolecules that play a vital role in various cellular processes such as differentiation, proliferation and apoptosis, and their deregulation is effective in the development of many types of cancer ${ }^{2}$. The miR-34 family, which was characterized in 2007, has three members, miR-34a-5p, miR-34b and miR-34c. The miR-34 family of tumor suppressor miRNAs is known to target many cancer-related genes, including p 53 . It has been reported that these miRNA family members are deregulated in a large number of cancer types ${ }^{3}$. One of the other most important tumor suppressor miRNA is miR-145-5p. The expression level of miR-145-5p has been shown to be frequently decreased in many cancers, including colorectal cancer, hematological cancers, prostate cancer, ovarian cancer, B-cell tumor, and breast cancer ${ }^{4}$. Undoubtedly, it is extremely important in terms of the molecular mechanism of cancer to learn that this decrease in the expression levels of miR-34a-5p and miR-145$5 p$, whose expression levels are found to be decreased in many cancers, contribute to the cancerization process by increasing their expression of target genes ${ }^{4,5}$. However, studies on miR34a-5p and miR-145-5p miRNAs targeting which genes in breast cancer and through which pathways are effective in the cancer process are limited.

Within the scope of the study, it was aimed to investigate the effects of related miRNAs on cell proliferation by transfection of mimic miR-145-5p and miR-34a-5p to MDA-MB-231 cells, which are triple negative breast cancer cell line.

Afterwards, the expression levels of one of the target genes of miR-34a-5p, Mouse double minute 4 (MDM4), E2F1, Insulinlike growth factor 1 receptor (IGF1R), MEK1, CDK4, cluster of differentiation 44 (CD44), eukaryotic translation initiation factor $4 \mathrm{E}$ (EIF4E) targeted by neurogenic locus notch homolog protein 2 (NOTCH2) and target genes of miR-145-5p, CDK4, Cyclin-dependent kinase 6 (CDK6), Epidermal growth factor receptor (EGFR), SRY-Box Transcription Factor (SOX2), KLF4, jagged canonical notch ligand 1 (JAG1) genes were investigated and it was aimed to investigate whether the expression levels of related genes are correlated with miR-34a-5p and miR$145-5 p$. Finally, it was aimed to investigate the relationship of miR-34a-5p and miR-145-5p with metastasis by looking at the expression of epithelial mesenchymal transition (EMT) markers that are known to contribute to the metastatic process.

\section{MATERIALS AND METHODS}

\section{Cell Culture and miRNA Transfection}

For the functional study of miR-34a-5p and miR-145-5p noncoding RNAs in vitro, MDA-MB-231 breast cancer cell line 1\% antibiotic (penicillin/streptomycin) and 10\% fetal bovine serum (Gibco, Thermo Fisher Scientific Inc., Waltham, MA, USA) was cultured and replicated in RPMI-1640 (Roswell Park Memorial Institute-1640) (Gibco, Thermo Fisher Scientific, Waltham, MA, USA) medium at $37^{\circ} \mathrm{C}$ in a $5 \% \mathrm{CO}_{2}$ incubator.

In our study, in which an in vitro functional experiment of miR-34a-5p and miR-145-5p synthetic mimic (Thermo Fisher Scientific Inc.) was planned separately in replicated cells, an oligonucleotide sequence control miRNA (non-targeting control miRNA, control nt miRNA) (Thermo Fisher Scientific Inc.) that did not target any gene was used (miR-145-5p 5'-GUCCAGUUUUCCCAGGAAUCCCU-3'), non-targeting control miRNA (5'-UCACAACCUCCUAGAAAGAGUAGA-3'), miR-34a-5p (5'-UGGCAGUGUCUUAGCUGGUUGU-3').

24 hours after seeding the appropriate number of cells (well/300,000 cells) on 6-well plates, transfection of miRNA mimic was performed in the cells. Mimics were transported into the cell with Lipofectamine 2000 reagent (Thermo Fisher Scientific Inc.) by applying the manufacturer's protocol in transfection. Then, the cells were incubated at $37^{\circ} \mathrm{C}$ and 24 
hours after transfection, cells transfected with miR-145-5p, miR-34a-5p and cells transfected with non-targeting control miRNA were taken separately in $1000 \mu \mathrm{L}$ Trizol (MRC Inc.) in eppendorfs and RNA was then brought to $-80{ }^{\circ} \mathrm{C}$ for isolation.

\section{Isolation of RNA from Cells After Transfection}

Total RNA was isolated from cells taken in trizol (MRC Inc.) in accordance with the manufacturer's protocol, and RNA concentration and purity were measured with the help of NanoDrop ND-2000c (Thermo Fisher Scientific Inc.) spectrophotometer.

\section{Confirmation of miRNA cDNA Synthesis and Transfection by miRNA qRT-PCR}

Using TaqMan probes, quantitative real-time polymerase chain reaction (qRT-PCR) was performed to determine the expression levels of miR-34a-5p and miR-145-5p in cell lines and to check whether the transfection processes were effective. MiRNA cDNA synthesis using total $30 \mathrm{ng}$ RNA was performed using TaqMan MicroRNA reverse transcriptase kit (Applied Bio., Foster City, CA, United States) and miRNA RT primers according to the manufacturer's protocol. TaqMan assays were used for qRTPCR, and qRT-PCR was performed on LightCycler 480 (Roche) instrument using TaqMan Universal Master Mix (Thermo Fisher Scientific Inc.) kit with TaqMan miRNA probes (Thermo Fisher Scientific Inc.) and RNU43 (control miRNA) probes (Thermo Fisher Scientific Inc.) according to the manufacturer's protocol. Experiments were performed in duplicate and $2^{-\Delta \Delta C t}$ method was used for relative quantitation analysis.

\section{In Silico Prediction of Target Genes for Expression of miR- 34a-5p and miR-145-5p After Transfection}

Target prediction tools for prediction of related genes which are the tools such as miRBase (http://www.mirbase.org/), miRWalk (http://mirwalk.umm.uni-heidelberg.de/) and miRTargetLink (https://ccb-web.cs.uni-saarland.de/mirtargetlink/) and databases such as Genecards, NCBI, PubMed were used. That the relationship of the gene selected to be investigated selectively in the prediction phase of possible target genes and the related miRNA has not been shown in the MDA-MB-231 breast cancer cell line before, that the expression level of the selected gene in breast cancer has been shown to increase in breast cancer previously in the literature, and that the selected gene is targeted by the relevant miRNA at least in two different cancers were taken into account. The miRTargetLink database was also used to schematize genes with strong interactions of miR-34a-5p and miR-145-5p ${ }^{6}$.

\section{cDNA Synthesis and qRT-PCR Procedures for the Target Genes of miR-34a-5p and miR-145-5p}

The cDNA extraction with SCRIPT cDNA synthesis kit (Jena Bioscience) and qPCR SybrMaster (Jena Bioscience) and
qRT-PCR processes were performed in accordance with the manufacturer's protocol, using a total of $1000 \mathrm{ng}$ of RNA obtained from the study group and control group cells.

While the expression levels of MDM4, E2F1, IGF1R, MEK1, CDK4, $\mathrm{CD} 44$ and NOTCH2 genes were determined in miR-34a-5p transfected cells, the expression levels of EIF4E, EGFR, SOX2, $C D K 4, C D K 6, J A G 1$ and KLF4 genes were examined in miR-145$5 p$ transfected cells. The primer sequences of the examined genes are shown in Table 1. qRT-PCR processes were performed on a LightCycler 480 (Roche) device.

\begin{tabular}{|c|c|c|}
\hline Primer & Primer Sequence & References \\
\hline MDM4-F & 5'-CTAAGTCCTAAAGTGATGATACCGATGT-3' & \multirow{2}{*}{7} \\
\hline MDM4-R & 5'-AACTTTGAACAATCTGAATACCAATCC-3' & \\
\hline E2F1-F & 5'-CAGAGCAGATGGTATGG-3' & \multirow{2}{*}{8} \\
\hline E2F1-R & 5'-CTGAAAGTTCTCCGAAGA-3' & \\
\hline IGF1R-F & 5'-ПTTCCCACAGCAGTCCACCTC-3' & \multirow{2}{*}{9} \\
\hline IGF1R-R & 5'-AGCATCCTAGCCTTCTCACCC-3' & \\
\hline MEK1-F & 5'ATGCATGGAAAGCATGCTTGGTGCTACTGAA3' & \multirow{2}{*}{10} \\
\hline MEK1-R & 5'-TTCAGTAGCAGCAAAGCATGCTTCCATGCA-3' & \\
\hline CDK4-F & 5'-TGCCAATTGCATCGTTCACCGAG-3' & \multirow{2}{*}{11} \\
\hline CDK4-R & 5'-TGCCCAACTGGTCGGCTTCA-3' & \\
\hline$C D 44-\mathrm{F}$ & 5'-ACTGCAGCCAACTTCGAGG -3' & \multirow{8}{*}{12} \\
\hline CD44-R & 5'-GGAATACACCTGCAAAGCGG-3' & \\
\hline SOX2-F & 5'-CTCCGGGACATGATCAGC-3' & \\
\hline SOX2-R & 5'-GGTAGTGCTGGGACATGTG-3' & \\
\hline KLF4-F & 5'-СССААТТАСССАТССТТСТG & \\
\hline KLF4-R & 5'-GTCTCCCCTCTIGGGCTG & \\
\hline$\beta$-aktin-F & 5'-GCCTCGCCTाTGCCGATC-3' & \\
\hline$\beta$-aktin-R & 5'-CCCACGATGGAGGGGAAG-3' & \\
\hline $\mathrm{NOTCH} 2-\mathrm{F}$ & 5'-GGGACCCTGTCATACCCTCT-3' & \multirow{2}{*}{13} \\
\hline NOTCH2-R & 5'-GAGCCATGCTTACGCTTTCG-3' & \\
\hline EIF4E-F & 5'-TACTAAGAGCGGCTCCACCAC-3' & \multirow{2}{*}{14} \\
\hline EIF4E-R & 5'-TCGATTGCTTGACGCAGTCTCC-3' & \\
\hline EGFR-F & 5'-ATGGTCAAGTGCTGGATG-3' & \multirow{2}{*}{15} \\
\hline EGFR-R & 5'-GAGGAAGGTGTCGTCTATG-3' & \\
\hline CDK6-F & 5'-TGGAGACCTTCGAGCACC -3' & \multirow{2}{*}{16} \\
\hline CDK6-R & 5'-CACTCCAGGCTCTGGAACT-3' & \\
\hline$J A G 1-\mathrm{F}$ & 5'-GCTTGGATCTGTTGCTTGGTGA -3' & \multirow{2}{*}{17} \\
\hline JAG1-R & 5'-ACTTTCCAAGTCTCTGTTGTCCTG-3' & \\
\hline E-Cad-F & 5'-TGCCCAGAAAATGAAAAAGG-3' & \multirow{6}{*}{18} \\
\hline E-Cad-R & 5'-GTGTATGTGGCAATGCGTC-3' & \\
\hline$N-C a d-F$ & 5'-ACAGTGGCCACCTACAAAGG-3' & \\
\hline N-Cad-R & 5'-CCGAGATGGGGTTGATAATG-3' & \\
\hline Vimentin-F & 5'-GAGAACTाGCCGTTGAAGC-3' & \\
\hline Vimentin-R & 5'-GCTTCCTGTAGGTGGCAATC-3' & \\
\hline
\end{tabular}




\section{Investigation of the Effect of miR-34a-5p and miR-145-5p on Cell Proliferation}

After cells were transfected with miR-34a-5p and miR-145$5 p$ synthetic mimic and control miRNA (non-targeting control miRNA), whether there was a change in the proliferation of cells were examined using the Cell Proliferation Reagent Water Soluble Tetrazolium Salt-8 (WST-8) (EcoTech Biotechnology) according to the manufacturer's protocol.

Cells seeded in triplicate at 5000 cells per well on 96 -well plates were cultured at $37{ }^{\circ} \mathrm{C}$ in a $5 \% \mathrm{CO}_{2}$ incubator. Proliferation changes in cells transfected after 24 hours were measured at the following $24^{\text {th }}, 48^{\text {th }}$ and $72^{\text {nd }}$ hours. For measurement, $10 \mu \mathrm{L}$ of WST-8 (EcoTech Biotechnology) solution was added to each well and cells were incubated at $37^{\circ} \mathrm{C}$ for three hours in the dark. Cell viability was evaluated using a plate reader (Thermo Varioskan flash) device capable of measuring absorbance at $450 \mathrm{~nm}$.

\section{Investigation of the Effect of miR-34a-5p and miR-145-5p on Cell Migration with EMT Marker}

In order to examine whether the transfected miRNAs contribute to the migration and invasion potential of cells, the expression levels of E-cadherin, $\mathrm{N}$-cadherin, Vimentin genes, which are important EMT markers in epithelial mesenchymal transition, were evaluated by qRT-PCR technique. qRT-PCR processes were performed using qPCR SybrMaster (Jena Bioscience) in accordance with the manufacturer's protocol.

\section{Statistical Analysis}

For normalization of gene expression, $\beta$-actin primers were used as internal control and experiments were performed in duplicate. The $2^{-\Delta \Delta C t}$ method was used for the relative quantitation analysis. Statistical analyzes were performed using Student's t-test and data were presented as mean \pm standard deviation. Data with a $p$ value less than 0.05 were considered statistically significant. GraphPad Prism 5 and Statistical Package for the Social Sciences 21 programs were used for graphic drawings.

\section{RESULTS}

\section{Verification of Transfection Procedures}

It was confirmed that the transfection occurred significantly for both miRNAs in miR-34a-5p and miR-145-5p transfected cells and control cells (Figure 1).

\section{Effect of miR-34a-5p and miR-145-5p on Expression Level of Possible Target Genes in MDA-MB-231 Cells}

As a result of the literature review and in silico studies, the expression of E2F1, MEK1 and CDK4 genes, which are among the genes that are predicted to be strongly associated with miR-34a-5p, were significantly suppressed in miR-34a-5p transfected cells compared to the control group (respectively $p=0.009 ; p=0.001 ; p=0.005$ ) and KLF4 gene, which is among the genes predicted to be strongly associated with miR-145$5 p$, was significantly suppressed in miR-145-5p transfected cells compared to the control group ( $p=0.007$ ) (Figure 2, 3, 4, $5)$.

\section{Effect of miR-34a-5p and miR-145-5p on Proliferation and Migration of MDA-MB-231 Cells}

It was determined that proliferation in MDA-MB-231 cells transfected with both miR-34a-5p and miR-145-5p decreased in correlation with the literature (Figures 6, 7).

As a result of expression evaluation of epithelial-mesenchymal cell markers with qRT-PCR to understand whether selected miRNAs have any regulatory role in cell migration, it was

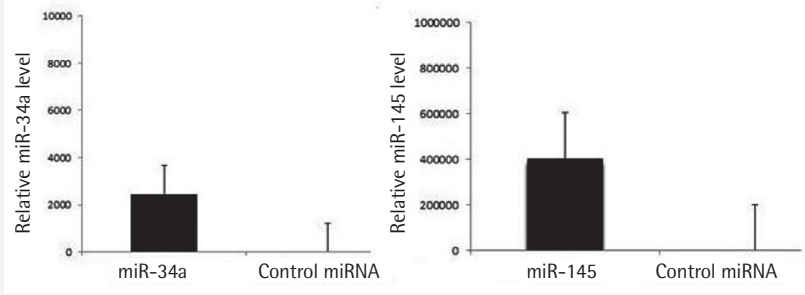

Figure 1. Verification of transfection miRNAs: MicroRNAs

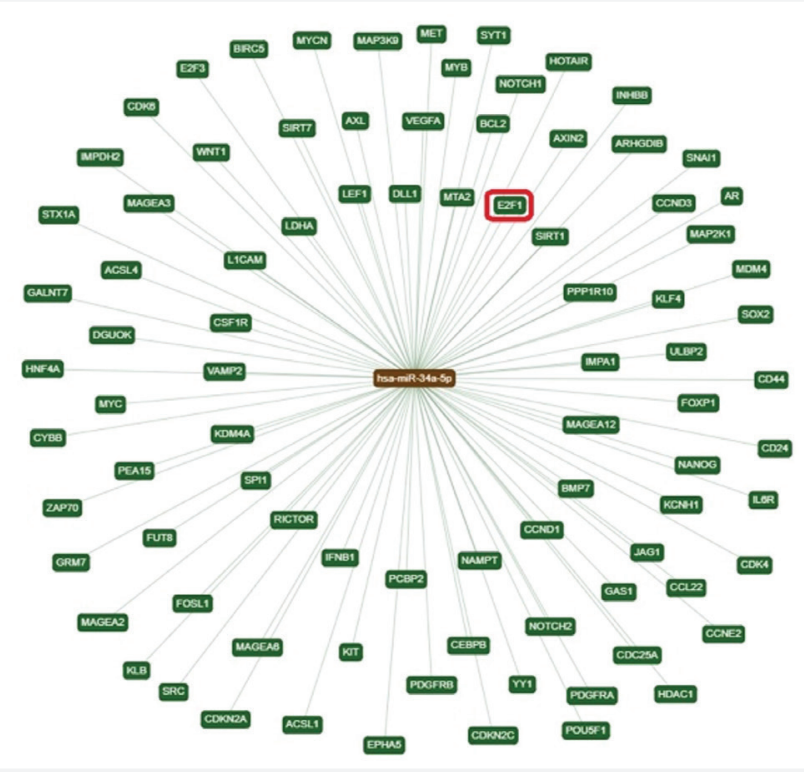

Figure 2. Genes predicted to be strongly associated with miR-34a-5p (https://ccb-web.cs.uni-saarland.de/ mirtargetlink/network.php) 
determined that E-Cad expression level was increased significantly $(p=0.01 ; p=0.0005$ respectively), Vimentin expression level was decreased significantly $(p=0.008 ; p=0.006$, respectively), and $\mathrm{N}$-Cad expression level was not changed significantly ( $p>0.05$ ) (Figure 8,9 ) in cells transfected with miR-34a-5 $p$ and miR-145-5p compared to control cells.

As a result, it was determined that miR-34a-5p and miR-145$5 p$ contributed to the suppression of cell migration in MDAMB-231 breast cancer cells by regulating through EMT markers.

\section{DISCUSSION}

MiRNAs, which can act as oncogene (onco-mir) or tumor suppressor (TSmir) according to the genes they target, are

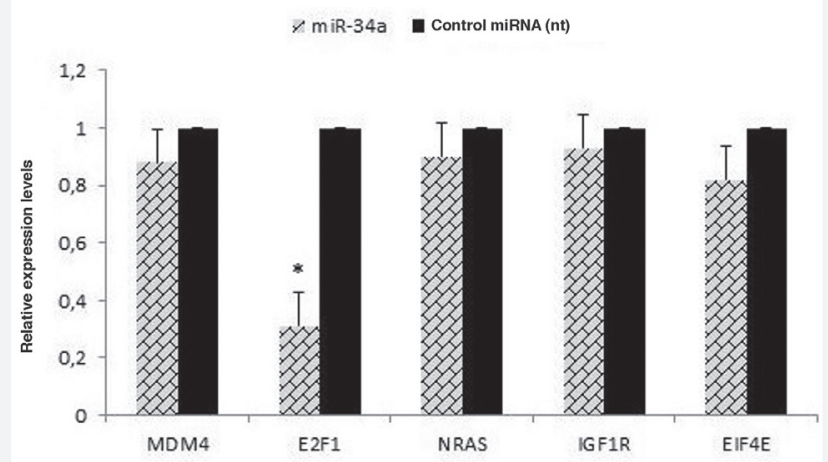

Figure 3. Effect of miR-34a-5p on expression levels of possible target genes in MDA-MB-231 cells miRNAs: MicroRNAs

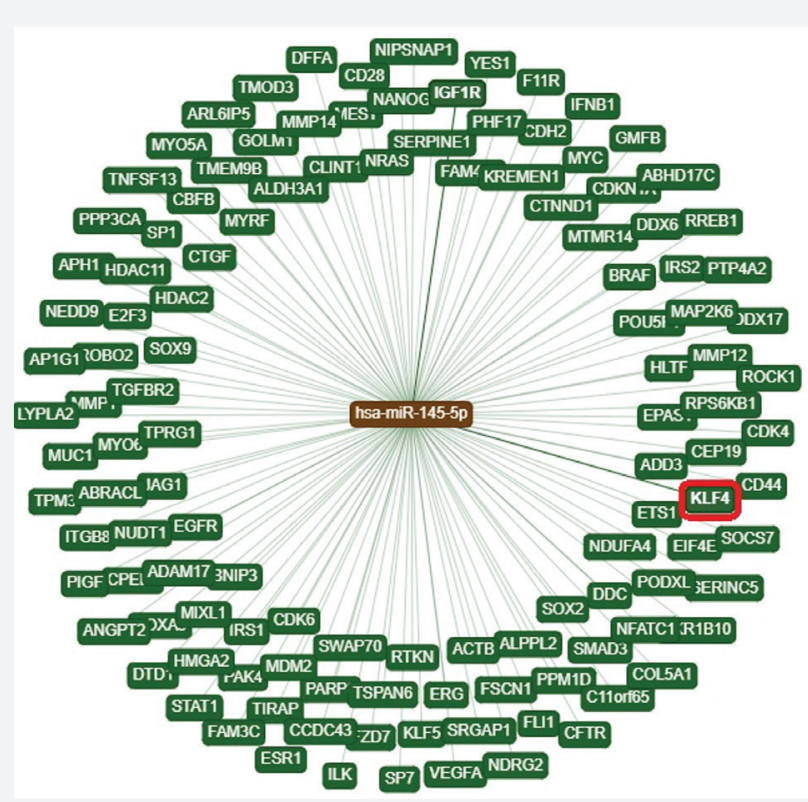

Figure 4. Genes predicted to be strongly associated with miR-145-5p (https://ccb-web.cs.uni-saarland.de/ mirtargetlink/network.php) among the most interesting research topics in recent years ${ }^{19}$. Abnormal expression changes in miRNAs may be involved in the cancer process by changing the expression of many genes targeted by the relevant miRNAs. The fact that miR-34 was the first miRNA to be tested in phase 1 in relation to the use of

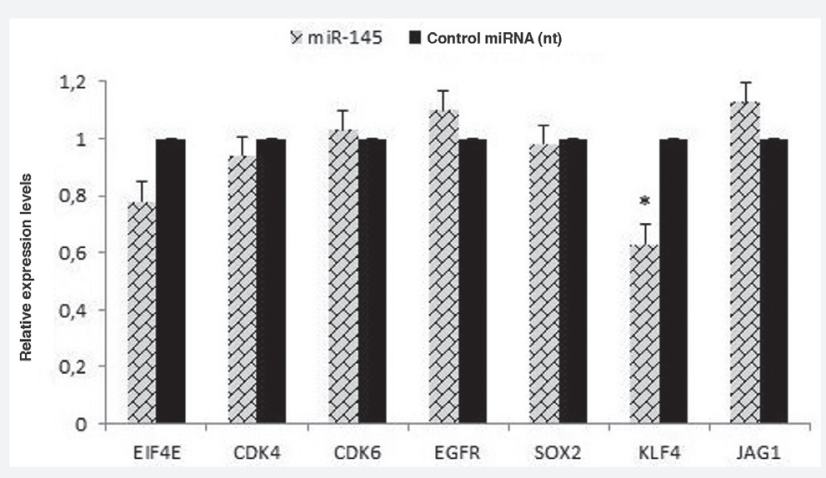

Figure 5. Effect of miR-145-5p on expression levels of possible target genes in MDA-MB-231 cells miRNAs: MicroRNAs

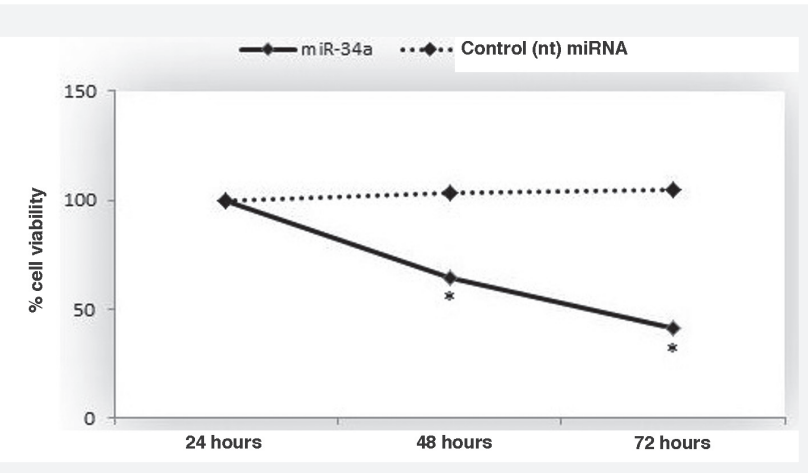

Figure 6. Effect of miR-34a-5p on proliferation in MDAMB-231 cells miRNAs: MicroRNAs

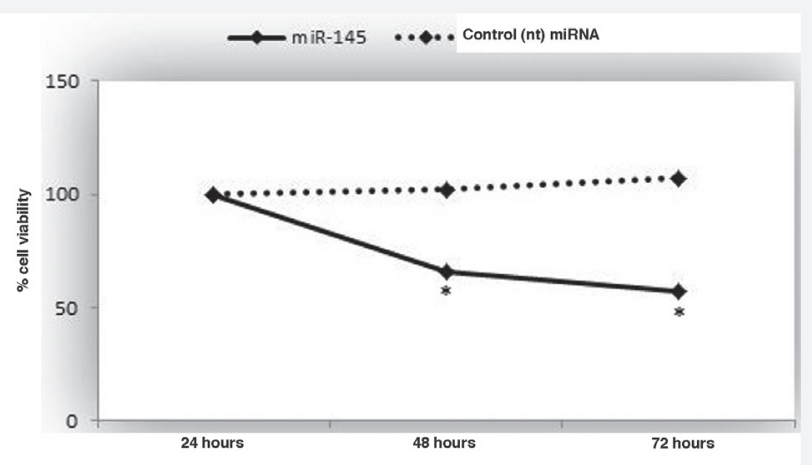

Figure 7. Effect of miR-145-5p on proliferation in MDAMB-231 cells miRNAs: MicroRNAs 
miRNAs in therapy indicates that miR-34 may be one of the most promising miRNAs in the future ${ }^{20}$.

Studies with miR-34a-5p localized at $1 p 36.22$ have shown that ectopic expression of miR-34a-5p directly or indirectly causes a decrease in the expression of many proto-oncogenes, resulting in decreased cancer cell proliferation and elimination of metastasis $^{5}$. The fact that $p 53$, which is shown as the guardian of the genome, and its homologous $p 63$ and p73 genes are controlled by miR-145-5p, and many important genes are targeted by this miRNA, indicates that miR-145-5p can have critical importance in early diagnosis and possible miRNA-based therapies ${ }^{4}$. Determining which genes control various cellular processes by regulating miRNAs is extremely important for understanding diseases at the molecular level ${ }^{21}$. miRNAs are involved in regulating the expression of most protein-coding genes at the post-transcriptional stage. Therefore, many bioinformatics tools have been created to predict the interaction between miRNA and target mRNA.

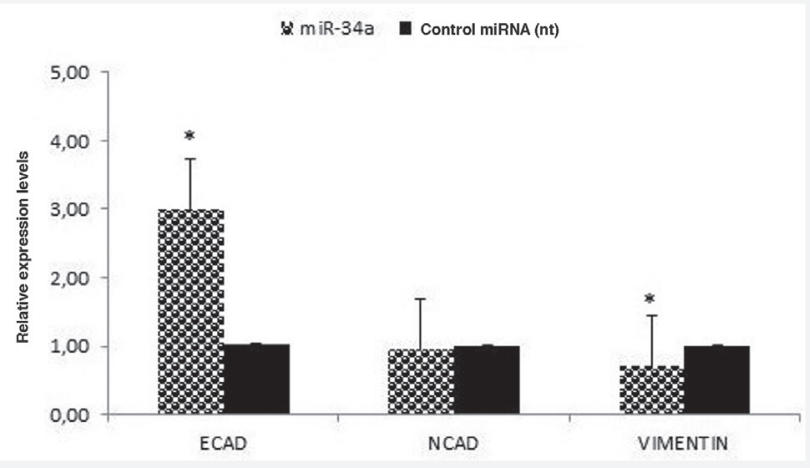

Figure 8. Effect of miR-34a-5p on expression levels of epithelial mesenchymal transition genes in MDA-MB-231 cells

miRNAs: MicroRNAs

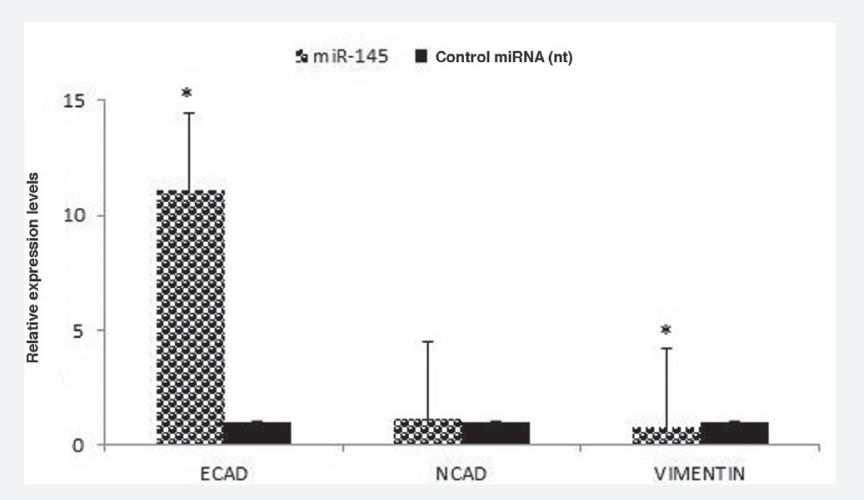

Figure 9. Effect of miR-145-5p on expression levels of epithelial mesenchymal transition genes in MDA-MB-231 cells

miRNAs: MicroRNAs
Supporting in vitro and in vivo predictions based on base pairing between miRNA and mRNA in silico may be important for the development and progression of many diseases, especially cancer, and the development of biomarkers for these diseases ${ }^{2}$. Figure 2 and Figure 4 show that miR-34a-5p and miR-145$5 p$ can target hundreds of genes in silico. In the literature, it has been shown that the expression levels of miR-34a-5p and miR-145-5p are considerably reduced in breast cancer patient tissue samples and MDA-MB-231 cells, as in many other cancer types $^{22,23}$. Therefore, according to the results of our transfection study to investigate the effects of miR-34a-5p and miR-145$5 p$ on MDA-MB-231 cells, miR-34a-5p and miR-145-5p have been found to have a significant effect on MDA-MB-231 cell proliferation. The effects of miR-34a-5p and miR-145-5p on cell proliferation may be related to decreased expression of various genes targeted by these miRNAs. The KLF4 gene is a gene that has been found to be highly expressed in more than $70 \%$ of breast cancers and has been reported to function as an oncogene ${ }^{24}$. The E2F1 gene is also a gene with increased expression in breast cancer and associated with breast cancer metastasis ${ }^{25}$. MEK 1 and CDK4 genes, whose expression levels have been found to be increased in many cancers, including breast cancer, are important oncogenes that play critical roles in apoptosis, migration, invasion and cell proliferation processes $^{26,27}$. miR-34a-5p of the E2F1, MEK1 and CDK4 genes; despite the fact that KLF4 has been shown to be effective in various cancer processes by being targeted by miR-145-5p, there are no studies in the literature on this subject in breast cancer $^{28-32}$. In our study to fill this gap in the literature, it was determined that E2F1, MEK1, CDK4 and KLF4 gene expression levels were significantly decreased in MDA-MB-231 cells transfected with mimic miR-34a-5p and mimic miR-145-5p.

\section{Study Limitations}

Considering our study results and the information in the literature together, it can be predicted that miR-34a-5p may contribute to the cancer process by targeting E2F1, MEK1 and CDK4 genes, and miR-145-5p targeting KLF4 in breast cancer. Among the limitations of the study; the fact that the research was carried out in cell line, it was not confirmed in the tissue, and the genes whose expression level was examined were examined only at the mRNA level. It is obvious that more meaningful results can be obtained if the findings obtained in our study at the level of RNA expression are supported by methods such as Western-Blot and luciferase activity determination in new studies on the subject.

It was seen that $\mathrm{CD} 44^{33}, \mathrm{NOTCH} 2^{34}, \mathrm{MDM}^{35}, \mathrm{IGF1R}^{36}$ genes, which have been shown as targets of miR-34a-5p both in silico and in vivo, and similarly the expression levels of EIF4E ${ }^{37}$, $E G F R^{38}$, SOX $2^{21}, C D K 4^{37}, C D K 6^{39}, J A G 1^{40}$ genes which have been shown as targets of miR-145-5p did not have a statistically 
significant change in MDA-MB-231 cells in which transfection of miRNA mimics was carried out in our study.

\section{CONCLUSION}

The data obtained from our study may be evidence that the miRNA-mRNA pairing created by theoretical prediction or the miRNA-mRNA relationship shown in vivo media in different cancer types may not be seen likewise in all cancer types due to the complex nature of cancer.

\section{Acknowledgement}

We would like to thank our esteemed professors, Prof. Dr. Şükrü Palanduz, Prof. Dr. Şükrü Öztürk, Prof. Dr. Kıvanç Çefle and Prof. Dr. Uğur Gezer for the encouragement and support they have shown us in our work.

\section{Ethics}

Ethics Committee Approval: Ethics committee approval form was not received because it was studied with cell lines.

Informed Consent: Patient samples were not studied.

Peer-review: Externally and internally peer-reviewed.

\section{Authorship Contributions}

Concept-Design: I.S., M.K., E.Ö., Data Collection or Processing: i.S., M.K., E.Ö., Analysis or Interpretation: I.S., M.K., E.Ö., Literature Search: I.S., M.K., E.Ö., Writing: I.S., M.K., E.Ö.

Conflict of Interest: No conflict of interest was declared by the authors.

Financial Disclosure: The authors declared that this study received no financial support.

\section{References}

1. Torre LA, Bray F, Siegel RL, Ferlay J, Lortet-Tieulent J, Jemal A. Global cancer statistics, 2012. CA Cancer J Clin. 2015;65:87-108.

2. Bartel DP. MicroRNAs: target recognition and regulatory functions. Cell. 2009;136:215-33

3. Engkvist ME, Stratford EW, Lorenz S, Meza-Zepeda LA, Myklebost 0 , Munthe E. Analysis of the miR-34 family functions in breast cancer reveals annotation error of miR-34b. Sci Rep. 2017;7:9655

4. Ding $Y$, Zhang C, Zhang J, Zhang N, Li T, Fang J, et al. miR-145 inhibits proliferation and migration of breast cancer cells by directly or indirectly regulating TGF- $\beta 1$ expression. Int J Oncol. 2017;50:1701-10.

5. Luo L, Zhang Y, He H, Chen C, Zhang B, Cai M. LncRNA FEZF1-AS1 Sponges miR-34a to Upregulate Notch-1 in Glioblastoma. Cancer Manag Res. 2020:12:1827-33.

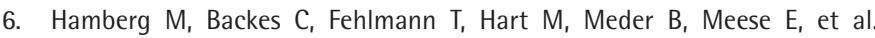
MiRTargetLink--miRNAs, Genes and Interaction Networks. Int J Mol Sci. 2016;17:564.

7. Bao J, Nanding A, Song $H, X u R, Q u G, X u e Y$. The overexpression of MDM4: an effective and novel predictor of gastric adenocarcinoma lymph node metastasis. Oncotarget. 2016;7:67212-22.
8. Ma X, Gao Y, Fan Y, Ni D, Zhang Y, Chen W, et al. Overexpression of E2F1 promotes tumor malignancy and correlates with TNM stages in clear cell renal cell carcinoma. PLoS One. 2013;8:e73436.

9. Guo B, Zhao Z, Wang Z, Li Q, Wang X, Wang W, et al. MicroRNA-302b-3p Suppresses Cell Proliferation Through AKT Pathway by Targeting IGF-1R in Human Gastric Cancer. Cell Physiol Biochem. 2017;42:1701-11.

10. Bluhm B, Ehlen HWA, Holzer T, Georgieva VS, Heilig J, Pitzler L, et al. miR322 stabilizes MEK1 expression to inhibit RAF/MEK/ERK pathway activation in cartilage. Development. 2017;144:3562-77.

11. Li E, Zhao Z, Ma B, Zhang J. Long noncoding RNA HOTAIR promotes the proliferation and metastasis of osteosarcoma cells through the AKT/mTOR signaling pathway. Exp Ther Med. 2017;14:5321-8.

12. Suer I, Karatas OF, Yuceturk B, Yilmaz M, Guven G, Buge O, et al Characterization of stem-like cells directly isolated from freshly resected laryngeal squamous cell carcinoma specimens. Curr Stem Cell Res Ther. 2014:9:347-53.

13. Wang C, Zhang W, Zhang L, Chen X, Liu F, Zhang J, et al. miR-146a-5p mediates epithelial-mesenchymal transition of oesophageal squamous cell carcinoma via targeting Notch2. Br J Cancer. 2018;118:e12.

14. Zhao Y, Yan M, Yun Y, Zhang J, Zhang R, Li Y, et al. MicroRNA-455-3p functions as a tumor suppressor by targeting elF4E in prostate cancer. Oncol Rep. 2017;37:2449-58.

15. Zhang B, Tian Y, Jiang P, Jiang Y, Li C, Liu T, et al. MicroRNA-122a Regulates Zonulin by Targeting EGFR in Intestinal Epithelial Dysfunction. Cell Physiol Biochem. 2017:42:848-58.

16. Shao $Y, Q u$ Y, Dang $S, Y a o$ B, Ji M. MiR-145 inhibits oral squamous cell carcinoma (OSCC) cell growth by targeting c-Myc and Cdk6. Cancer Cell Int. 2013;13:51.

17. Butler JM, Nolan DJ, Vertes EL, Varnum-Finney B, Kobayashi H, Hooper AT, et al. Endothelial cells are essential for the self-renewal and repopulation of Notch-dependent hematopoietic stem cells. Cell Stem Cell. 2010;6:251-64.

18. Wang X, Yang J, Qian J, Liu Z, Chen H, Cui Z. S100A14, a mediator of epithelial-mesenchymal transition, regulates proliferation, migration and invasion of human cervical cancer cells. Am J Cancer Res. 2015;5:1484-95.

19. Yavuzșen HT, Aktaş S, Saatli HB, Altun ZS. micro RNAs in Ovarian Cancer. DEU Tip Derg. 2019;33:93-101.

20. Agostini $M$, Knight RA. miR-34: from bench to bedside. Oncotarget. 2014;5:872-81.

21. Ozen $M$, Karatas OF, Gulluoglu S, Bayrak OF, Sevli S, Guzel E, et al. Overexpression of miR-145-5p inhibits proliferation of prostate cancer cells and reduces SOX2 expression. Cancer Invest. 2015;33:251-8.

22. Wang S, Bian C, Yang Z, Bo Y, Li J, Zeng L, Zhou H, Zhao RC. miR-145 inhibits breast cancer cell growth through RTKN. Int J Oncol. 2009;34:1461-6.

23. Li L, Yuan L, Luo J, Gao J, Guo J, Xie X. MiR-34a inhibits proliferation and migration of breast cancer through down-regulation of $\mathrm{BCl}-2$ and SIRT1. Clin Exp Med. 2013;13:109-17.

24. Yu F, Li J, Chen H, Fu J, Ray S, Huang S, et al. Kruppel-like factor 4 (KLF4) is required for maintenance of breast cancer stem cells and for cell migration and invasion. Oncogene. 2011;30:2161-72.

25. Hollern DP, Swiatnicki MR, Rennhack JP, Misek SA, Matson BC, McAuliff A et al. E2F1 Drives Breast Cancer Metastasis by Regulating the Target Gene FGF13 and Altering Cell Migration. Sci Rep. 2019;9:10718.

26. Zuo H, Xiong J, Chen $\mathrm{H}$, Liu S, Gong $\mathrm{O}$, Guo F. The Involvement of p53-miR34a-5p-CDK4 Signaling During the Development of Cervical Cancer. Cancer Transl Med. 2015;1:67-71.

27. Zhou Y, Hu HY, Meng W, Jiang L, Zhang X, Sha JJ, et al. MEK inhibitor effective against proliferation in breast cancer cell. Tumour Biol. 2014;35:9269-79.

28. Han R, Chen X, Li Y, Zhang S, Li R, Lu L. MicroRNA-34a suppresses aggressiveness of hepatocellular carcinoma by modulating E2F1, E2F3, and Caspase-3. Cancer Manag Res. 2019;11:2963-76.

29. Huang S, Guo W, Tang Y, Ren D, Zou X, Peng X. miR-143 and miR-145 inhibit stem cell characteristics of PC-3 prostate cancer cells. Oncol Rep. 2012;28:1831-7. 
30. Minami K, Taniguchi K, Sugito N, Kuranaga $Y$, Inamoto T, Takahara K, et al. MiR-145 negatively regulates Warburg effect by silencing KLF4 and PTBP1 in bladder cancer cells. Oncotarget. 2017;8:33064-77.

31. Ichimura A, Ruike Y, Terasawa K, Shimizu K, Tsujimoto G. MicroRNA$34 a$ inhibits cell proliferation by repressing mitogen-activated protein kinase kinase 1 during megakaryocytic differentiation of K562 cells. Mol Pharmacol. 2010;77:1016-24.

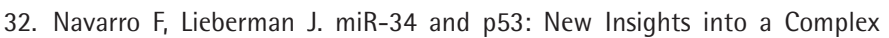
Functional Relationship. PLoS One. 2015;10:e0132767.

33. Liu C, Kelnar K, Liu B, Chen X, Calhoun-Davis T, Li H, et al. The microRNA miR-34a inhibits prostate cancer stem cells and metastasis by directly repressing CD44. Nat Med. 2011;17:211-5.

34. Li Y, Guessous F, Zhang Y, Dipierro C, Kefas B, Johnson E, et al. MicroRNA34 a inhibits glioblastoma growth by targeting multiple oncogenes. Cancer Res. 2009;69:7569-76.

35. Mandke P, Wyatt N, Fraser J, Bates B, Berberich SJ, Markey MP. MicroRNA34a modulates MDM4 expression via a target site in the open reading frame. PLoS One. 2012;7:e42034.
36. Helwak A, Kudla G, Dudnakova T, Tollervey D. Mapping the human miRNA interactome by CLASH reveals frequent noncanonical binding. Cell. 2013;153:654-65.

37. Chen $Z$, Zeng $H$, Guo $Y$, Liu $P$, Pan $H$, Deng $A$, et al. miRNA-145 inhibits non-small cell lung cancer cell proliferation by targeting c-Myc. J Exp Clin Cancer Res. 2010;29:151.

38. Cho WC, Chow AS, Au JS. MiR-145 inhibits cell proliferation of human lung adenocarcinoma by targeting EGFR and NUDT1. RNA Biol. 2011;8:125-31.

39. Li Y, Liu J, Liu ZZ, Wei WB. MicroRNA-145 inhibits tumour growth and metastasis in osteosarcoma by targeting cyclin-dependent kinase, CDK6. Eur Rev Med Pharmacol Sci. 2016;20:5117-25.

40. Condorelli AG, Logli E, Cianfarani F, Teson M, Diociaiuti A, El Hachem M, et al. MicroRNA-145-5p regulates fibrotic features of recessive dystrophic epidermolysis bullosa skin fibroblasts. Br J Dermatol. 2019;181:1017-27. 